\title{
PENINGKATAN PERTUMBUHAN DAN HASIL KARET MELALUI SISTEM TUMPANG SARI BERBASIS KARET \\ (Improvement The Growth and Yield of Rubber Through Rubber Based Intercropping \\ System)
}

\author{
Sahuri* \\ Pusat Penelitian Karet Sembawa \\ J1. Raya Palembang-P. Balai Km 29, PO BOX: 1127, Palembang 30001 \\ *E-mail: sahuri_agr@ymail.com
}

Tanggal diterima: 4 Maret 2020; Tanggal disetujui: 21 April 2020; Tanggal direvisi: 30 April 2020

\begin{abstract}
The rubber intercropping system with other economic crops can increase land productivity and rubber productivity. This study aimed to research the effects of intercropping treatments towards soil fertility, development of rubber girth expansion, latex yield, and potential intercrops yields. The study was conducted at the experimental plantation of Sembawa Rubber Research Center using a Randomized Block Design with three replications. The treatment factors are four cropping patterns, i.e: PT1 (monoculture rubber); PT2 (rubber pineapple); PT3 (rubber+sweet corn); and PT4 (rubber+cayenne pepper). Observed parameters in this study included rubber girth expansion, bark thickness, amount of tappable trees, amount of latex yield, and amount of potential intercrops yields. The data were statistically analyzed using ANOVA, followed by DMRT at the level of 5\%. The results showed that intercropping treatment significantly affects the growth of rubber trees and reduces unproductive plant phases. Rubber trees in the intercropping treatment were ready for tapping five months earlier than in the monoculture rubber trees. However, the bark thickness was similar to that of the monoculture rubber trees. Intercropping treatments had no effect on latex yield per tree per tapping, but yield per hectare was greater in the intercropping treatments than monocultur rubber trees due to the number of trees that could be tapped was significantly higher.
\end{abstract}

Keywords: Agro-forestry, rubber growth, latex yield, rubber intercrops

\begin{abstract}
ABSTRAK
Tumpang sari karet dengan tanaman ekonomis lainnya dapat meningkatkan produktivitas lahan dan produktivitas karet. Penelitian ini bertujuan untuk mengetahui pengaruh perlakuan tumpang sari terhadap kesuburan tanah, pertumbuhan lilit batang karet/keliling batang karet, hasil lateks, dan potensi hasil tanaman sela. Penelitian dilaksanakan di Kebun Percobaan Pusat Penelitian Karet Sembawa menggunakan Rancangan Acak Kelompok dengan tiga ulangan. Faktor perlakuan ada empat pola tanam, yaitu PT1 (karet monokultur); PT2 (karet+nanas); PT3 (karet+jagung manis); dan PT4 (karet+cabai rawit). Parameter yang diamati meliputi: lilit batang karet, tebal kulit batang, matang sadap pohon karet, hasil lateks, potensi hasil tanaman sela dan analisis kesuburan tanah. Hasil penelitian menunjukkan bahwa perlakuan tumpang sari berpengaruh nyata terhadap peningkatan pertumbuhan pohon karet dan mengurangi fase tanaman yang tidak produktif. Pohon karet dengan perlakuan tumpang sari siap untuk disadap lima bulan lebih awal daripada pohon karet monokultur. Sementara ketebalan kulit batang karet tidak berbeda nyata daripada pohon karet monokultur. Perlakuan tumpang sari tidak memberikan pengaruh terhadap hasil lateks per pohon per penyadapan, tetapi hasil per hektar lebih besar dengan perlakuan tumpang sari karena jumlah pohon yang dapat disadap lebih tinggi secara nyata.
\end{abstract}

Kata kunci: Agroforestri, pertumbuhan, hasil lateks, tanaman sela 


\section{PENDAHULUAN}

Tumpang sari karet dengan tanaman ekonomis lainnya dapat meningkatkan produktivitas lahan dan produktivitas karet (Mousavi \& Eskandari, 2011; Ferry, Pranowo \& Rusli, 2013; Sahuri \& Rosyid, 2015; Sahuri, 2019). Sistem tumpang sari karet juga dapat meningkatkan efisiensi penggunaan lahan (Ogwuche, Umar, Esekhade, \& Francis, 2012; Pansak, 2015; Sahuri, Cahyo, \& Nugraha, 2016; Hondrade et al., 2017; Romyen, Sausue, \& Charenjiratragul, 2018).

Beberapa hasil penelitian pola tumpang sari karet dengan tanaman pangan (misalnya dengan padi gogo, jagung, kedelai, dan lain-lain), hortikultura (misalnya dengan nanas, pisang, cabai, dan lain-lain), dan tanaman perkebunan lainnya (seperti kakao, kopi, sawit, tebu, dan lain-lain) telah didokumentasikan dari tahun 1980-an dalam laporan penelitian tahunan Pusat Penelitian Karet Sembawa. Hasil penelitian menunjukkan bahwa tidak ada efek negatif dari perlakuan tumpang sari terhadap pertumbuhan pohon karet (Sahuri \& Rosyid, 2018; Sahuri \& Rosyid, 2015; Sahuri, 2019). Penelitian di tempat lain juga menunjukkan hasil yang sama seperti tumpang sari karet dengan padi gogo dan kacang hijau (Hondrade et al., 2017).

Tumpang sari diantara pohon karet berjarak tanam $6 \mathrm{~m} \times 3 \mathrm{~m}$ atau $7 \mathrm{~m} \times 3 \mathrm{~m}$ hanya dapat dilakukan saat pohon karet berumur 1-2 tahun setelah tanam, lebih dari itu tajuk atau kanopi pohon karet sudah menutup (Xianhai, Mingdao, \& Weifu, 2012; Sahuri, 2019c). Pada pohon karet berumur $>2$ tahun pengurangan cahaya dapat mencapai $50 \%$ dan tanaman sela yang ditanam di bawah naungan 50\% memberikan hasil yang lebih rendah dibandingkan dengan keadaan tanpa naungan dengan penurunan hasil mencapai 60\% (Fikriati, 2010; Pringadi, Toha, \& Guswara, 2012; Sahuri, 2019).

Sedikit penelitian yang menilai pengaruh pola tumpang sari karet terhadap pertumbuhan dan hasil karet setelah tanaman sela diantara pohon karet sudah tidak ada. Di sisi lain ketika merekomendasikan tumpang sari karet sangat penting melihat bagaimana pengaruh tumpang sari baik terhadap pertumbuhan pohon karet saat belum matang sadap maupun terhadap hasil lateks ketika sudah matang sadap. Oleh karena itu, penelitian ini bertujuan untuk mengetahui pengaruh perlakuan tumpang sari terhadap kesuburan tanah, pertumbuhan lilit batang/keliling batang pohon karet, tebal kulit pohon karet, hasil lateks, dan potensi hasil tanaman sela (nanas, jagung manis, dan cabai rawit) pola tumpang sari.

\section{METODOLOGI}

\section{A. Lokasi dan Waktu Penelitian}

Penelitian dilaksanakan di Kebun Percobaan Pusat Penelitian Karet Sembawa, Sumatera Selatan pada jenis tanah ultisol yang sudah tidak memiliki lapisan top soil dari tahun 2014 sampai tahun 2019 (5 tahun). Areal penelitian terletak pada $104^{\circ} 32,4^{\prime}$ BT dan $03^{\circ} 55,7^{\prime}$ LS serta ketinggian $10 \mathrm{~m}$ dari permukaan laut $(\mathrm{m} \mathrm{dpl})$. Topografi areal sebagian besar relatif datar dengan lereng antara 0$10 \%$. Lokasi penelitian dipilih pada areal kebun karet klon IRR 112 yang cukup seragam dengan jarak tanam $6 \mathrm{~m} \times 3 \mathrm{~m}$ (populasi 550 pohon/ha).

\section{B. Metode}

Penelitian ini merupakan penelitian faktor tunggal menggunakan Rancangan Acak Kelompok dengan tiga kelompok. Faktor perlakuan terdiri dari empat pola tanam yaitu: PT1: karet monokultur; PT2: karet+nanas, PT3: karet+jagung manis; dan PT4: karet+cabai rawit. Jarak tanam, waktu tanam, dan dosis pupuk yang digunakan untuk tanaman sela disajikan pada Tabel 1, sedangkan jadwal dan dosis pemupukan pohon karet disajikan pada Tabel 2. 
Parameter pohon karet yang diamati adalah pertumbuhan lilit batang pohon karet atau keliling batang pohon karet $(\mathrm{cm})$, tebal kulit pohon karet $(\mathrm{mm})$ dan hasil lateks pada pohon matang sadap (gram/pohon/penyadapan). Lilit batang atau keliling batang pohon karet diukur pada ketinggian $100 \mathrm{~cm}$ dari pertautan okulasi (dpo), pada umur 12 sampai 60 bulan setelah tanam (BST) yang dibandingkan antara pohon karet pola tumpang sari dengan pola karet monokultur. Tebal kulit pohon karet diukur pada ketinggian $100 \mathrm{~cm}$ dari dpo pada umur 60 bulan setelah tanam yang dibandingkan antara pohon karet pola tumpang sari dengan pola karet monokultur. Pohon matang sadap mengikuti standar lilit batang pohon karet $\geq 45 \mathrm{~cm}$. Parameter tanaman sela yang diamati adalah produksi buah nanas, jagung manis, dan buah cabai rawit per ha. Luas plot tanaman sela diantara nanas, jagung manis, dan cabai rawit sebagai tanaman sela diantara pohon karet masingmasing 1 ha. Pengolahan tanah dilakukan pada tiap plot secara minimal (minimum tillage) dan pembersihan gulma. Jarak plot dari pohon karet 1-1,5 m dan jarak antara plot $1 \mathrm{~m}$. Pola tanam tumpang sari dapat dilihat pada Gambar 1.

Untuk mengetahui kondisi iklim setempat, maka dilakukan analisis data curah hujan dan laju evapotranspirasi yang diperoleh dari Stasiun Klimatologi dan Geofisika terdekat. Analisis kelas kesesuaian iklim untuk pohon karet menurut Wijaya, (2015). Selanjutnya dilakukan analisis tanah berdasarkan kriteria kesuburan tanah menurut Wijaya, (2018).

Tabel (Table) 1. Jarak tanam, waktu tanam, dan dosis pupuk untuk tanaman sela karet (Spacing, planting time, and dosage of fertilizer for rubber intercrops)

\begin{tabular}{|c|c|c|c|c|c|c|c|}
\hline \multirow[b]{2}{*}{$\begin{array}{c}\text { Tanaman sela } \\
\text { (Rubber intercrops) }\end{array}$} & \multirow[b]{2}{*}{$\begin{array}{c}\text { Jarak tanam } \\
(\text { Crop } \\
\text { distance }) \\
\left(\mathrm{cm}^{2}\right)\end{array}$} & \multirow[b]{2}{*}{$\begin{array}{c}\text { Jarak dari } \\
\text { pohon karet } \\
\text { (Distance from } \\
\text { rubber tree) } \\
(\mathrm{cm})\end{array}$} & \multirow[b]{2}{*}{$\begin{array}{l}\text { Waktu tanam } \\
\text { pada musim } \\
\text { hujan (Planting } \\
\text { time in rainy } \\
\text { season) }\end{array}$} & \multicolumn{4}{|c|}{ Pupuk (Fertilizer) (kg/ha) } \\
\hline & & & & Urea & $\begin{array}{l}\mathrm{KCl} \\
\text { (Potassium } \\
\text { Chloride) }\end{array}$ & $\begin{array}{l}\text { TSP (Triple } \\
\text { Super } \\
\text { Phosphate) }\end{array}$ & $\begin{array}{l}\text { Dolomit } \\
\text { (Dolomite) }\end{array}$ \\
\hline $\begin{array}{l}\text { 1. Nanas } \\
\text { (Pineapple) }\end{array}$ & $100 \times 50$ & 150 & Awal & 300 & 150 & 200 & 750 \\
\hline $\begin{array}{l}\text { 2. Jagung manis } \\
\text { (Sweet corn) }\end{array}$ & $80 \times 20$ & 100 & Pertengahan & 350 & 150 & 250 & 750 \\
\hline $\begin{array}{l}\text { 3. Cabai rawit } \\
\text { (Cayenne pepper) }\end{array}$ & $80 \times 60$ & 100 & Pertengahan & 150 & 100 & 150 & 750 \\
\hline Keterangan (Remarks) & $\begin{array}{l}\text { Populasi } \\
\text { dengan } \\
\text { pineapple } \\
\text { distance }\end{array}$ & the row of $r$ & ela sebagai & (7) & karet a & 50600 & lture $w$ \\
\hline
\end{tabular}

Tabel (Table) 2. Jadwal pemupukan untuk pohon karet (Fertilizer schedule for rubber tree)

\begin{tabular}{|c|c|c|c|}
\hline \multirow[b]{2}{*}{ Jenis pupuk (Fertilizer type) } & \multicolumn{3}{|c|}{$\begin{array}{c}\text { Jumlah pupuk (kg/pohon/tahun) (Amount of fertilizer) } \\
(\mathrm{kg} / \text { tree/year })\end{array}$} \\
\hline & $\begin{array}{c}\text { Tahun keempat } \\
\text { setelah tanam }\left(4^{\text {th }}\right. \\
\text { year after planting })\end{array}$ & $\begin{array}{c}\text { Tahun kelima setelah } \\
\text { tanam sebelum disadap } \\
\left(5^{\text {th }} \text { year after planting }\right. \\
\text { before tapping) }\end{array}$ & $\begin{array}{l}\text { Saat disadap } \\
\text { (Tapping } \\
\text { period) }\end{array}$ \\
\hline 1. Urea & 0,75 & 0,60 & 0,85 \\
\hline $\begin{array}{l}\text { 2. TSP (Triple Super } \\
\text { Phosphate) }\end{array}$ & 0,78 & 0,50 & 0,44 \\
\hline 3. $\mathrm{KCl}$ (Potassium Chloride) & 0,50 & 0,50 & 0,70 \\
\hline 4. Kiserit (Kieserite) & 0,23 & 0,20 & 0,15 \\
\hline
\end{tabular}

Keterangan (Remarks): Dosis pupuk yang digunakan berdasarkan hasil analisis hara tanah dan daun (The fertilizer dosage used was based on the results of soil and leaf nutrient analysis) 


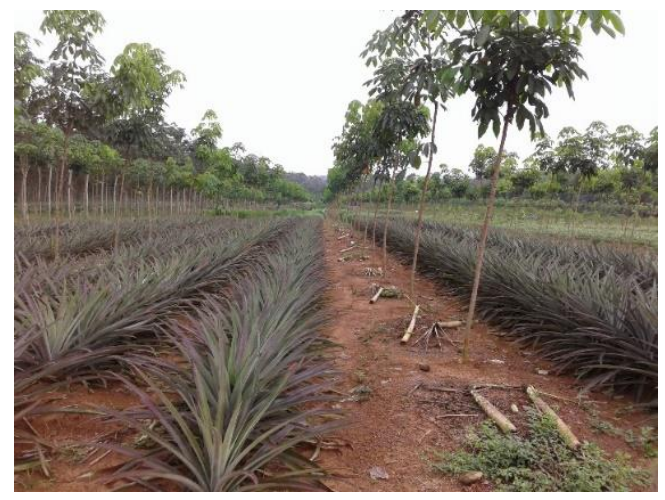

PT2

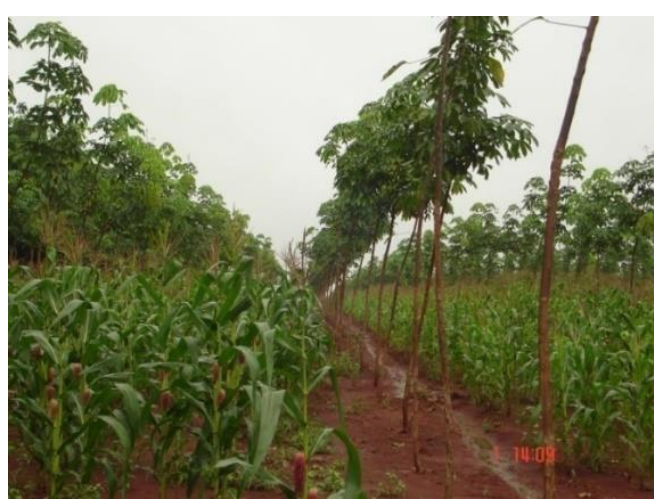

PT3

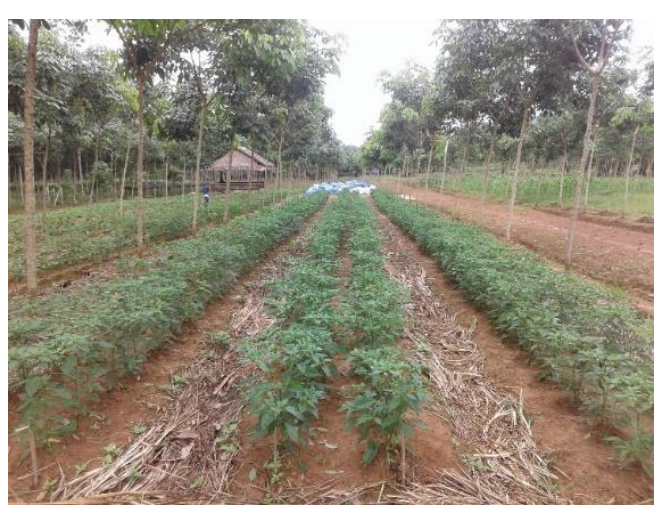

PT4

Gambar (Figure) 1. Plot tumpang sari (Intercropping plots), PT2 = Tanaman karet + nanas $($ Rubber + pineapple $), \mathrm{PT} 3=$ Tanaman karet + jagung manis $($ Rubber + sweet corn $)$, dan PT4 = Tanaman karet + cabai rawit $($ Rubber + cayenne pepper)

\section{Analisis Data}

Data yang diperoleh dianalisis menggunakan sidik ragam, jika berbeda nyata dilanjutkan dengan uji lanjut Duncan Multiple Range Test pada taraf 5\%.

\section{HASIL DAN PEMBAHASAN}

\section{A. Hasil}

\section{Kondisi iklim lokasi penelitian}

Rata-rata curah hujan bulanan, laju evapotranspirasi, dan jadwal penanaman tanaman sela pada musim tanam 2014 sampai 2019 di Stasiun Pusat Penelitian Sembawa disajikan pada Gambar 2. Jenis tanah di lokasi penelitian adalah ultisol.
Rata-rata curah hujan tahun 2014-2019 di lokasi penelitian adalah $2.036 \mathrm{~mm} /$ tahun dengan curah hujan tertinggi pada bulan November-April (> $200 \mathrm{~mm}$ ) dan bulan kering Mei-Oktober $(<100 \quad \mathrm{~mm})$. Berdasarkan rata-rata curah hujan bulanan dari tahun 2014 sampai 2019 menunjukkan bahwa lokasi penelitian termasuk dalam Tipe Iklim C3, yaitu tipe iklim yang agak lembab dengan jumlah bulan basah (curah hujan > $200 \mathrm{~mm}$ ) antara 5-6 bulan dan jumlah bulan kering (curah hujan $<100$ $\mathrm{mm}$ ) antara 4-6 bulan (As-Syakur, 2009). Kondisi ini menunjukkan bahwa penanaman tanaman sela semusim di antara pohon karet secara optimal hanya dapat dilakukan satu kali dalam setahun. Berdasarkan kelas kesesuaian iklim untuk 
pohon karet, maka lokasi penelitian termasuk kelas S2 (agak sesuai).

\section{Analisis tanah}

Hasil analisis tanah di lokasi penelitian menunjukkan bahwa adanya tanaman sela diantara pohon karet berpengaruh positif terhadap peningkatan kesuburan lahan karet. Hasil analisis $\mathrm{pH}$ tanah menunjukkan bahwa $\mathrm{pH}$ tanah meningkat dari sangat masam menjadi masam, C-organik meningkat dari rendah menjadi tinggi dan $\mathrm{P}$ meningkat dari rendah menjadi sedang, sedangkan $\mathrm{N}, \mathrm{K}$, dan KTK masih rendah (Tabel 3). Kesuburan tanah karena adanya tanaman sela nyata meningkat daripada karet monokultur. Hal ini karena adanya input hara seperti pupuk anorganik dan pupuk organik serta pemeliharaan tanaman sela yang menyebabkan struktur tanah menjadi lebih baik dan kondisi tanah kaya akan unsur hara yang sangat dibutuhkan oleh tanaman karet.

\section{Lilit batang pohon karet}

Lilit batang pohon karet pada $100 \mathrm{~cm}$ di atas pertautan okulasi sampai pada pertumbuhan karet umur lima tahun ditunjukkan pada Gambar 3. Lilit batang karet yang diukur selama lima tahun pertumbuhan menunjukkan bahwa lilit batang pohon karet pola tumpang sari ternyata lebih besar $(\mathrm{P}=0,0062)$ daripada pohon karet monokultur yang meningkat seiring waktu dan umur tanaman (Gambar 3a). Laju pertumbuhan lilit batang pohon karet karena pola tumpang sari terbukti mencapai tingkat pertumbuhan lebih cepat daripada pohon karet monokultur selama periode percobaan lima tahun (Gambar 3b). Jika pertumbuhan pohon karet dianggap linier dari waktu ke waktu, maka pertumbuhan lilit batang pohon karet tahunan dengan pola tumpang sari mencapai 9,26 cm per tahun, sedangkan pohon karet monokultur hanya mencapai 8,54 cm per tahun (Gambar 3).

\section{Tebal kulit batang pohon karet}

Ketebalan kulit pohon karet merupakan salah satu faktor penentu hasil lateks. Ketebalan kulit pohon karet tidak dipengaruhi oleh perlakuan tumpang sari tetapi berubah seiring waktu. Ketebalan kulit batang pohon karet pola tumpang sari pada umur lima tahun setelah tanam tidak berbeda nyata dengan karet monokultur, yaitu masing-masing adalah $5,80 \mathrm{~mm}$ dan 5,75 $\mathrm{mm}$ (Gambar 4). Hal ini karena pengukuran hanya dilakukan pada pohon karet saat matang sadap. Tebal kulit batang pohon karet jelas meningkat ketika pohon tumbuh. Penelitian ini, menunjukkan bahwa perlakuan tumpang sari tidak memiliki efek negatif terhadap ketebalan kulit batang pohon karet. 


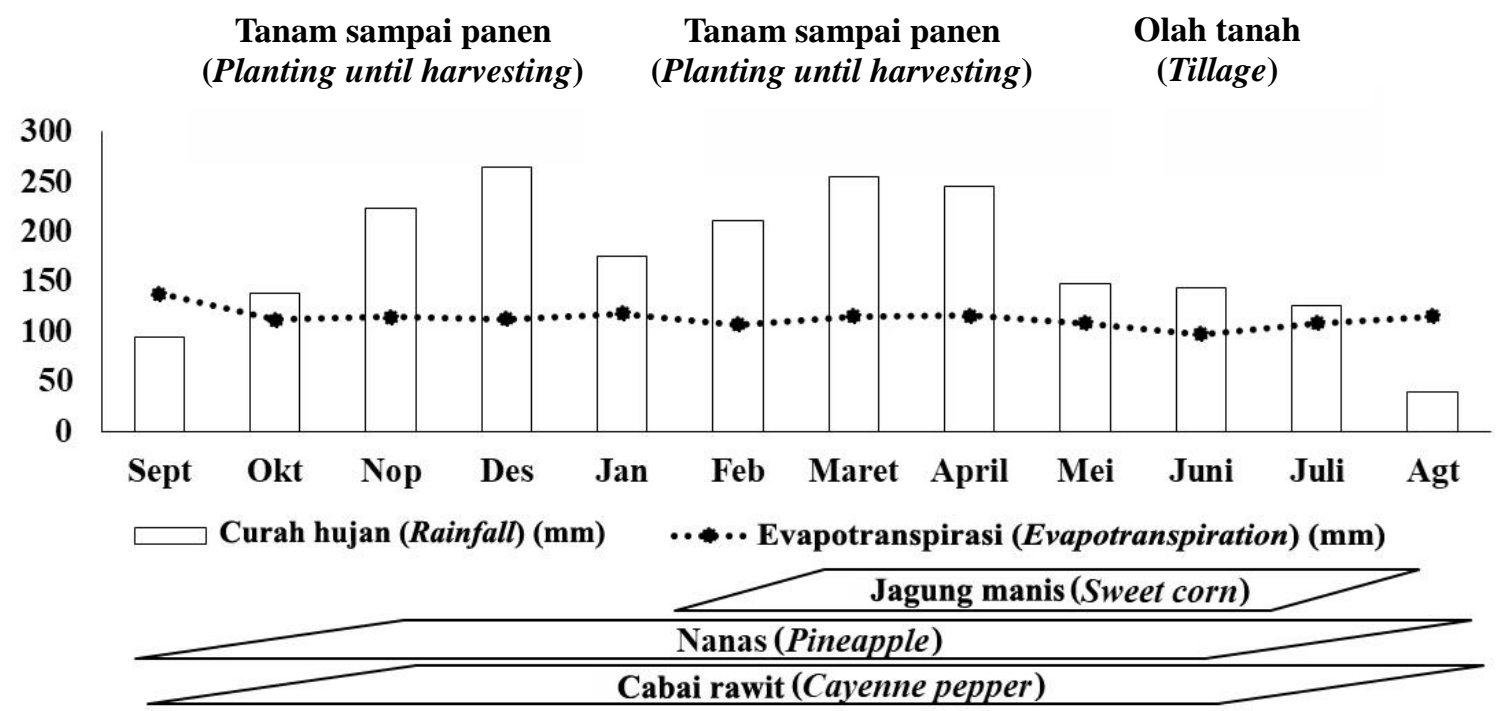

Gambar (Figure) 2. Rata-rata curah hujan bulanan, laju evapotranspirasi, dan jadwal penanaman tanaman sela pada musim tanam 2014-2019 di Stasiun Pusat Penelitian Sembawa (Average monthly rainfall, evapotranspiration rate, and the planting schedule of intercrops in the period of 2014-2019 growing season at Sembawa Research Center Station)

Tabel (Table) 3. Pengaruh tumpang sari karet/nanas/jagung manis/cabai rawit terhadap kesuburan tanah di antara pohon karet (Effects of rubber/pineapple/sweet corn/cayenne pepper intercropping in the soil in between rubber trees)

\begin{tabular}{lllllll}
\hline $\begin{array}{l}\text { Pola tanam } \\
\begin{array}{l}\text { Cropping } \\
\text { system) }\end{array}\end{array}$ & $\mathrm{pH}$ & C-organic & $\mathrm{N}$ & $\mathrm{P}_{2} \mathrm{O}_{5}$ & $\mathrm{~K}_{2} \mathrm{O}$ & $\mathrm{KTK}$ \\
\cline { 2 - 7 } PT1 & $4,39 \mathrm{~b}(\mathrm{sm})$ & $1,51 \mathrm{c}(\mathrm{r})$ & $0,24 \mathrm{c}(\mathrm{r})$ & $4,23 \mathrm{~b}(\mathrm{sr})$ & $0,15 \mathrm{a}(\mathrm{sr})$ & $6,198 \mathrm{~b}(\mathrm{r})$ \\
PT2 & $4,95 \mathrm{a}(\mathrm{m})$ & $4,07 \mathrm{ab}(\mathrm{t})$ & $0,31 \mathrm{~b}(\mathrm{r})$ & $9,20 \mathrm{a}(\mathrm{sd})$ & $0,19 \mathrm{a}(\mathrm{sr})$ & $14,05 \mathrm{a}(\mathrm{r})$ \\
PT3 & $5,22 \mathrm{a}(\mathrm{m})$ & $4,83 \mathrm{a}(\mathrm{t})$ & $0,31 \mathrm{~b}(\mathrm{r})$ & $8,48 \mathrm{a}(\mathrm{sd})$ & $0,21 \mathrm{a}(\mathrm{sr})$ & $11,43 \mathrm{a}(\mathrm{r})$ \\
PT4 & $4,94 \mathrm{a}(\mathrm{m})$ & $3,78 \mathrm{ab}(\mathrm{t})$ & $0,41 \mathrm{a}(\mathrm{r})$ & $7,39 \mathrm{a}(\mathrm{sd})$ & $0,21 \mathrm{a}(\mathrm{sr})$ & $12,01 \mathrm{a}(\mathrm{r})$ \\
\hline
\end{tabular}

Keterangan (Remarks): Kode perlakuan PT1, PT2, PT3, dan PT4 masing-masing merujuk pada tanaman karet monokultur dan pola tumpang sari dengan nanas, jagung manis, dan cabai rawit (Treatment codes PT1. PT2, PT3, and PT4 refer to monoculture rubber and rubber based intercropping with pineapple, sweet corn, and cayenne pepper intercrops, respectively); Angka-angka yang diikuti oleh huruf yang sama pada kolom yang sama berarti tidak berbeda nyata pada uji Duncan taraf 5\% (Means with the same letter within column are not significantly different $(P<$ 0.05). $\mathrm{sm}=$ sangat masam (very acid) $\mathrm{m}=$ masam (acid) $; \mathrm{t}=$ tinggi (height) $; \mathrm{sd}=$ sedang (moderate) $; \mathrm{r}=$ rendah $($ low $), \mathrm{sr}=$ sangat rendah $($ very low $)$ 

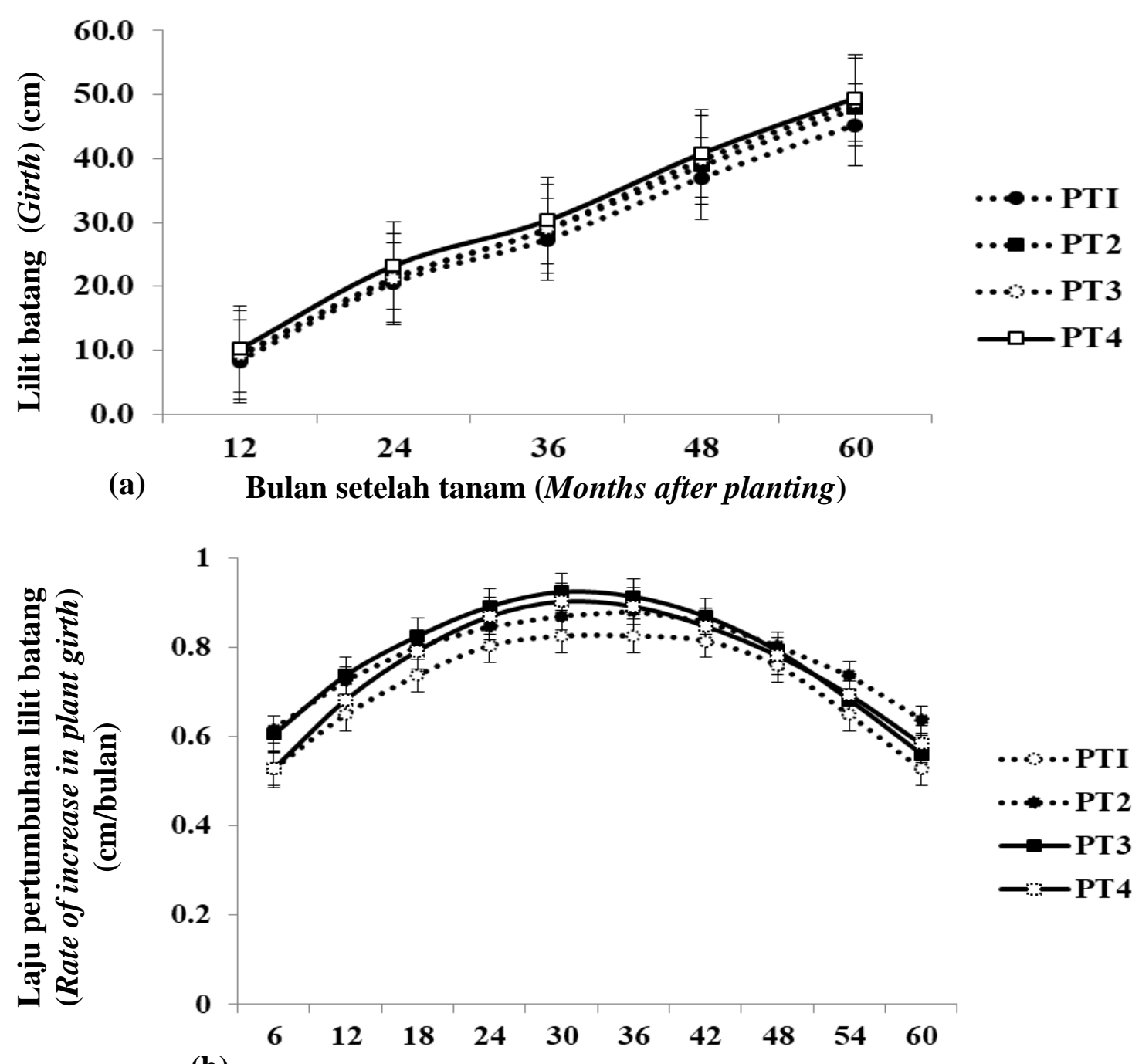

(b) Bulan setelah tanam (Months after planting)

Keterangan (Remarks): Kode perlakuan PT1, PT2, PT3, dan PT4 masing-masing merujuk pada tanaman karet monokultur dan pola tumpang sari dengan nanas, jagung manis, dan cabai rawit (Treatment codes PT1. PT2, PT3, and PT4 refer to monoculture rubber and rubber based intercropping with pineapple, sweet corn, and cayenne pepper intercrops, respectively) YPT1 $=-0.0138 \mathrm{x}^{2}+0.1529 \mathrm{x}+0.3385\left(\mathrm{r}^{2}=0.99\right) ;$ YPT2 $=-0.0113 \mathrm{x}^{2}+0.1255 \mathrm{x}+0.4498$ $\left(r^{2}=0.99\right)$; YPT3 $=-0.0152 x^{2}+0.1614 x+0.4058\left(r^{2}=0.99\right) ;$ YPT4 $=-0.0154 x^{2}+0.172 x+$ $0.3355\left(r^{2}=0.99\right)$

Gambar (Figure) 3. Pengaruh tumpang sari karet/nanas/jagung manis/cabai rawit pada (a) lilit batang dan (b) laju pertumbuhan lilit batang karet diukur pada ketinggian $100 \mathrm{~cm}$ di atas pertautan okulasi (Effects of rubber/pineapple/sweet corn/cayenne pepper intercropping on the (a) girth expansion and (b) estimated rate of girth increase of rubber measured at height of $100 \mathrm{~cm}$ above the bud-grafted union) 


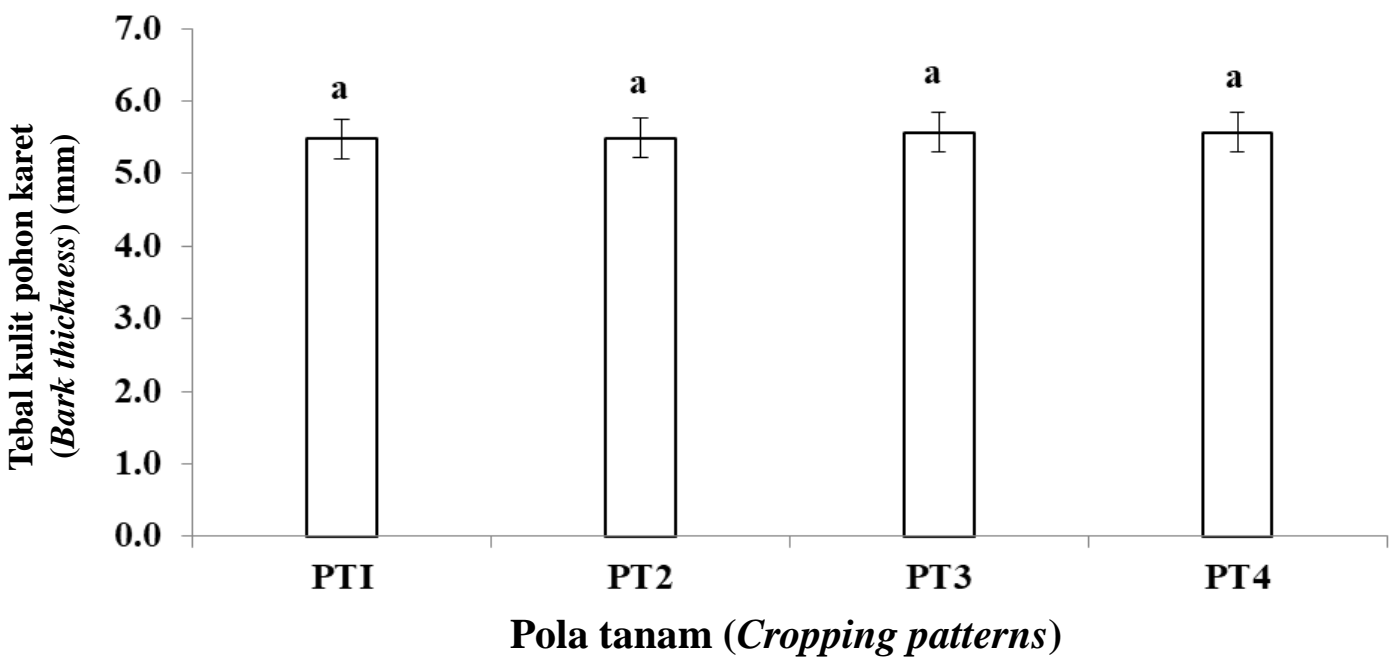

Keterangan (Remarks): Kode perlakuan PT1, PT2, PT3, dan PT4 masing-masing merujuk pada tanaman karet monokultur dan pola tumpang sari dengan nanas, jagung manis, dan cabai rawit (Treatment codes PT1. PT2, PT3, and PT4 refer to monoculture rubber and rubber based intercropping with pineapple, sweet corn, and cayenne pepper intercrops, respectively) Diagram batang yang diikuti oleh huruf yang sama berarti tidak berbeda nyata pada uji Duncan taraf 5\% (A bar chart followed by the same letter means that there is no significant in Duncan's test of 5\%)

Gambar (Figure) 4. Rata-rata tebal kulit pohon karet pada umur lima tahun yang diukur pada ketinggian $100 \mathrm{~cm}$ dari pertautan okulasi (Effects of intercropping treatment on bark thickness of rubber trees after 5 years growth based on girth measurements at heights $100 \mathrm{~cm}$ above bud-grafted union)

\section{Matang sadap pohon karet}

Pada tahun kelima, mayoritas pohon karet pada semua pola tumpang sari lebih dari $60 \%$ lilit batang pohon karet sudah mencapai $45 \mathrm{~cm}$ dibandingkan dengan pola karet monokultur (59\%). Pohonpohon karet dalam perlakuan tumpang sari dapat matang sadap (yaitu $45 \mathrm{~cm}$ ) lebih awal daripada pohon karet monokultur. Dengan demikian, pohon karet yang diperlakukan tumpang sari pada umur lima tahun siap untuk disadap lima bulan lebih awal daripada pada pohon karet monokultur. Proporsi pohon karet yang mencapai lilit batang melebihi $60 \%$ merupakan standar yang digunakan untuk memulai penyadapan secara komersial. Tidak hanya pada pohon-pohon karet contoh, tetapi di semua pohon karet pada pola tumpang sari memiliki matang sadap lebih awal daripada pohon karet monokultur. Hal ini terlihat dari ukuran lilit batang yang diukur pada ketinggian $100 \mathrm{~cm}$ dari pertautan okulasi umur 5 tahun setelah penanaman (Gambar 5).

\section{Hasil lateks}

Variasi musiman hasil lateks per pohon per penyadapan (gram/pohon/ penyadapan) ditunjukkan pada Gambar 6 . Tidak ada pengaruh perlakuan tumpang sari yang konsisten terhadap hasil lateks per pohon per penyadapan. Hasil lateks rendah pada bulan Agustus dan September karena bertepatan dengan musim kemarau (sedikit hujan turun) dan musim gugur daun selama bulan-bulan kering. Hasil lateks tinggi terjadi selama kuartal awal dan akhir tahun, karena bertepatan dengan musim penghujan dan dedaunan kanopi mulai membaik (Gambar 6). Jumlah pohon yang dapat disadap berdasarkan standar lilit batang pohon karet $\geq 45 \mathrm{~cm}$ secara statistik nyata lebih tinggi dengan 
perlakuan tumpang sari daripada perlakuan karet monokultur $(\mathrm{P}<0,0001)$ dengan hasil menunjukkan bahwa total hasil lateks selama 12 bulan secara konsisten lebih tinggi dengan perlakuan tumpang sari daripada perlakuan karet monokultur (Gambar 7).

\section{Potensi hasil nanas, jagung manis, dan cabai rawit sebagai tanaman di antara pohon karet}

Tanaman nanas, jagung manis, dan cabai rawit sebagai tanaman sela diantara pohon karet berjarak tanam $6 \mathrm{~m}$ x $3 \mathrm{~m}$ hanya dapat ditanam sampai pohon karet berumur 2 tahun. Populasi tanaman tersebut diantara pohon karet berjarak tanam $6 \mathrm{~m} \times 3 \mathrm{~m}$ adalah $60 \%$ dari populasi monokultur dengan jarak dari barisan pohon karet adalah 1,0-1,5 m. Potensi hasil nanas, jagung manis dan cabai rawit di sela pohon karet belum menghasilkan seluas 1 ha disajikan pada Tabel 4.

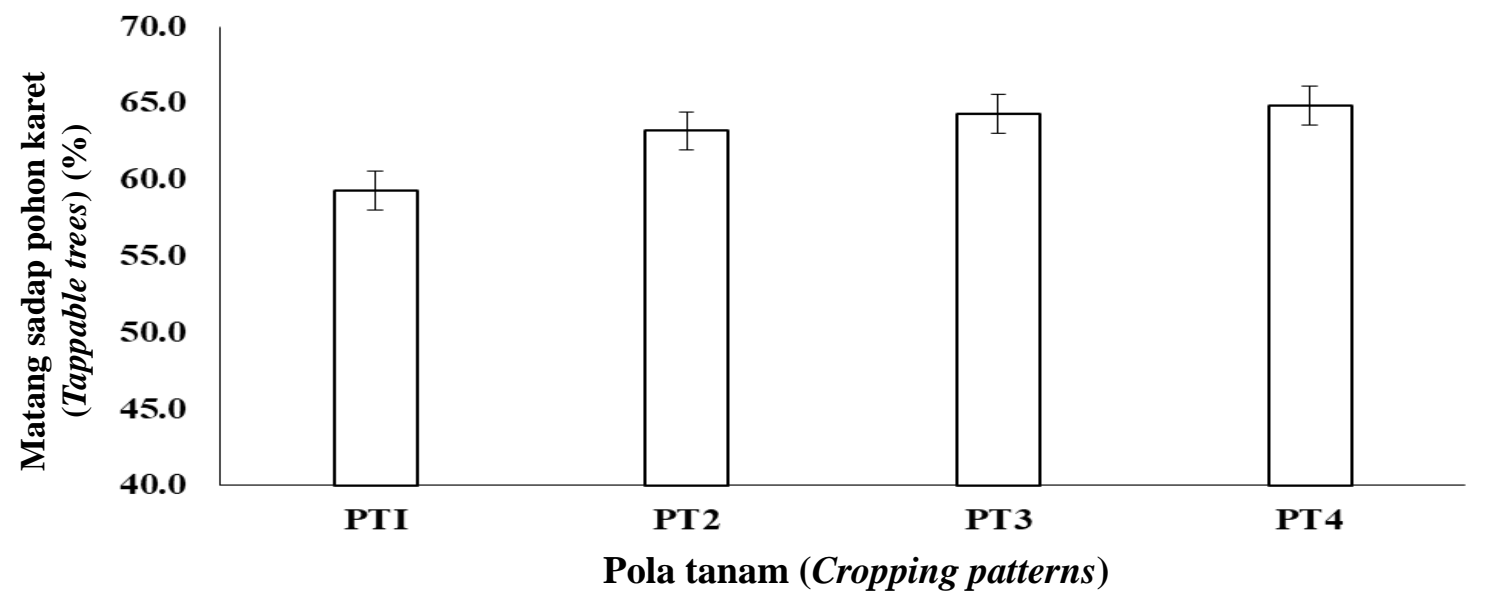

Keterangan (Remarks): Kode perlakuan PT1, PT2, PT3, dan PT4 masing-masing merujuk pada tanaman karet monokultur dan pola tumpang sari dengan nanas, jagung manis, dan cabai rawit (Treatment codes PT1. PT2, PT3, and PT4 refer to monoculture rubber and rubber based intercropping with pineapple, sweet corn, and cayenne pepper intercrops, respectively)

Diagram batang yang diikuti oleh huruf yang sama berarti tidak berbeda nyata pada uji Duncan taraf 5\% (A bar chart followed by the same letter means that there is no significant in Duncan's test of $5 \%$ )

Gambar (Figure) 5. Rata-rata persentase pohon karet yang sudah matang disadap pada perlakuan monokultur, tumpang sari dengan karet/nanas/jagung manis/cabai rawit terhadap pada umur lima tahun (Intercropping treatment effects on the average percentage of tapping trees after 5 years old) 


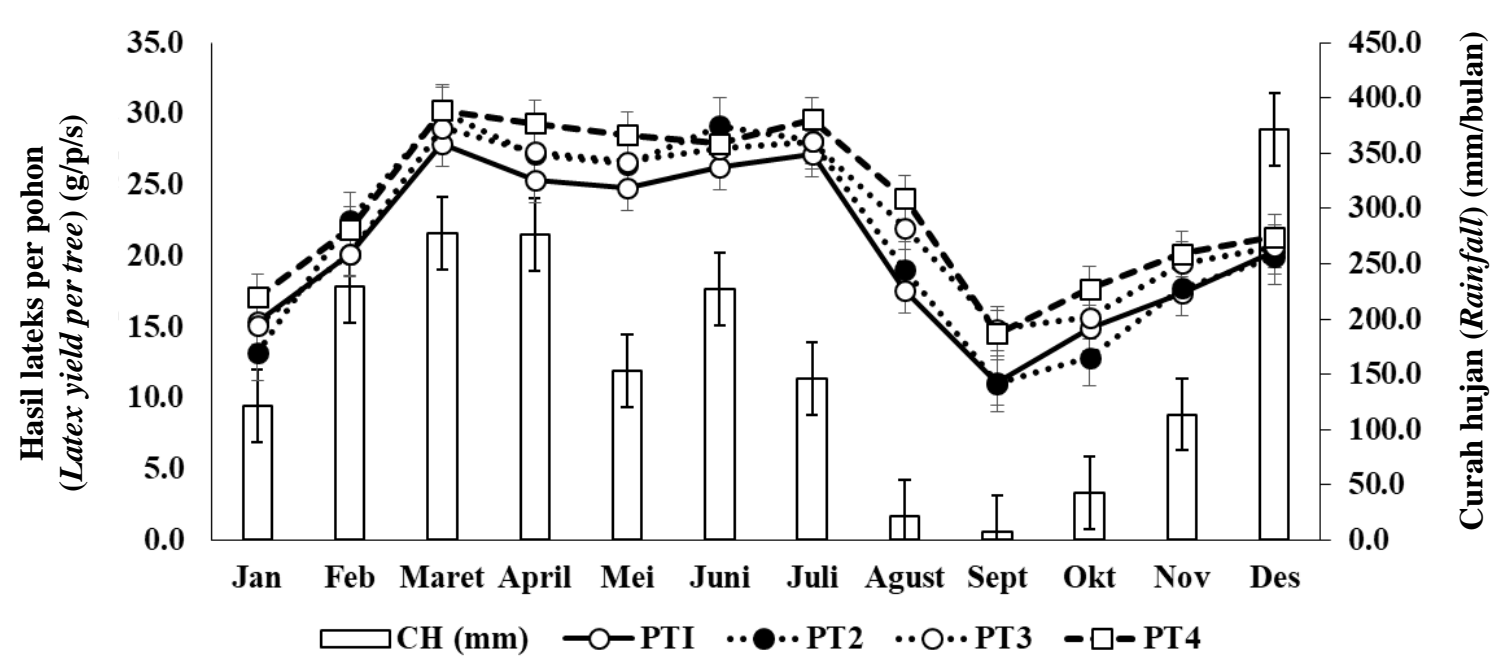

Keterangan (Remarks): Kode perlakuan PT1, PT2, PT3, dan PT4 masing-masing merujuk pada tanaman karet monokultur dan pola tumpang sari dengan nanas, jagung manis, dan cabai rawit (Treatment codes PT1. PT2, PT3, and PT4 refer to monoculture rubber and rubber based intercropping with pineapple, sweet corn, and cayenne pepper intercrops, respectively). $\mathrm{CH}=$ curah hujan (Rainfall)

Gambar(Figure) 6. Pengaruh perlakuan tumpang sari karet/nanas/jagung manis/cabai rawit terhadap hasil lateks per pohon karet per penyadapan (gram/pohon' penyadapan) (Intercropping treatment effects on latex yield of rubber at the individual tree level measured at individual harvests (gram/tree'tapping)

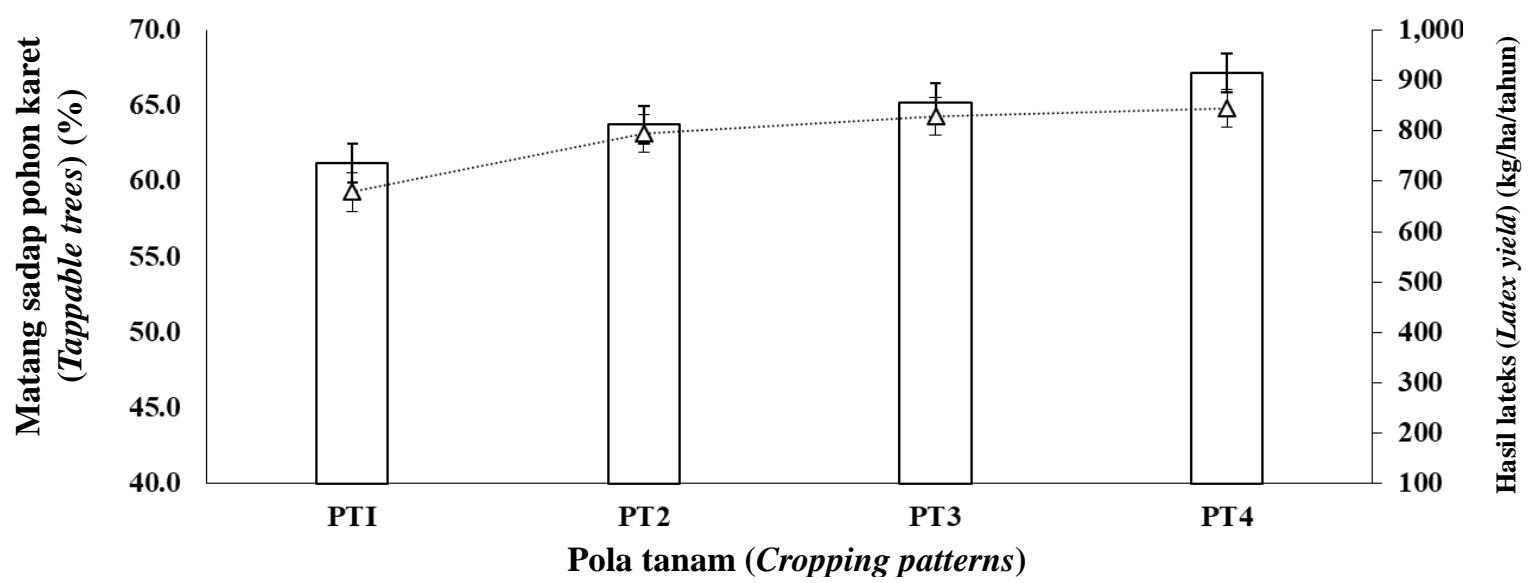

$\square$ Hasil lateks (Latex yield) (kg/ha/tahun (year) $\quad \cdots \cdots \cdots \cdots \cdot$ Matang sadap (Tappable trees) $(\%)$

Keterangan (Remarks): Kode perlakuan PT1, PT2, PT3, dan PT4 masing-masing merujuk pada tanaman karet monokultur dan pola tumpang sari dengan nanas, jagung manis, dan cabai rawit (Treatment codes PT1. PT2, PT3, and PT4 refer to monoculture rubber and rubber based intercropping with pineapple, sweet corn, and cayenne pepper intercrops, respectively)

Gambar (Figure) 7. Pengaruh perlakuan tumpang sari tumpang sari karet/nanas/jagung manis/cabai rawit terhadap hasil lateks per ha per tahun dan persentase matang sadap pohon karet (\%) (Intercropping treatment effects on $1^{\text {st }}$ yield rubber per ha and percentage of tapping trees) 
Tabel (Table) 4. Potensi hasil nanas, jagung manis dan cabai rawit di sela pohon karet belum menghasilkan seluas 1 ha (Potential yields of pineapple, sweet corn, and cayene pepper between immature rubber trees on an area of 1 ha)

\begin{tabular}{|c|c|c|c|c|c|c|}
\hline \multirow[b]{2}{*}{$\begin{array}{l}\text { Tanaman sela } \\
\text { (Rubber } \\
\text { intercrops) }\end{array}$} & \multicolumn{3}{|c|}{ Populasi per ha (Population per ha) } & \multicolumn{3}{|c|}{ Produksi (Productioni) (kg/ha) } \\
\hline & $\begin{array}{l}\text { Nanas } \\
\text { (Pineapple) }\end{array}$ & $\begin{array}{l}\text { Jagung } \\
\text { manis } \\
\text { (Sweet } \\
\text { corn) }\end{array}$ & $\begin{array}{l}\text { Cabai rawit } \\
\text { (Cayene } \\
\text { pepper) }\end{array}$ & $\begin{array}{l}\text { Nanas } \\
\text { (Pineapple) }\end{array}$ & $\begin{array}{l}\text { Jagung manis } \\
\text { (Sweet corn) }\end{array}$ & $\begin{array}{l}\text { Cabai rawit } \\
\text { (Cayene } \\
\text { pepper) }\end{array}$ \\
\hline $\begin{array}{l}\text { 1. Monokultur } \\
\text { (Monoculture) }\end{array}$ & 16.000 & 50.000 & 33.333 & 10.885 & 9.879 & 7.927 \\
\hline $\begin{array}{l}\text { 2. Tumpang sari } \\
\text { (Intercropping) }\end{array}$ & 7.520 & 24.000 & 15.667 & 6.637 & 6.098 & 4.834 \\
\hline
\end{tabular}

\section{B. Pembahasan}

Hasil penelitian menunjukkan bahwa pola tumpang sari karet berpengaruh positif terhadap peningkatan kesuburan tanah dan tidak menyebabkan persaingan unsur hara dalam tanah. Seperti yang dilaporkan Esekhade, Idoko, Osazuwa, Kore, \& Mesike, (2014), sistem tumpang sari karet nyata dapat meningkatkan karbon organik, unsur nitrogen, dan fosfor dalam tanah. Namun, jika tanahnya terus ditanami dalam jangka panjang akan terjadi penipisan unsur hara akibat dari perlakuan tumpang sari. Oleh karena itu, penambahan pupuk khususnya nitrogen, dan fosfor tetap dilakukan untuk meningkatkan pertumbuhan pohon karet dan tanaman selanya. Khongdee \& Pansak, (2015) juga melaporkan bahwa perlakuan tumpang sari karet tidak berpengaruh negatif terhadap kandungan hara dan kelembaban tanah, sehingga tidak menyebabkan persaingan unsur hara dalam tanah. Tumpang sari karet dengan pisang dapat meningkatkan karbon organik dan mikroba pengikat nitrogen (Tetteh et al., 2019).

Kesuburan tanah akibat adanya tumpang sari di tanaman karet menyebabkan pertumbuhan lilit batang (keliling) pohon karet meningkat daripada pohon karet monokultur. Laju pertumbuhan lilit batang pohon karet dengan pola tumpang sari terbukti mencapai tingkat pertumbuhan lebih cepat daripada pohon karet monokultur selama periode lima tahun. Riap tahunan lilit batang pohon karet pada umur lima tahun pada pola tumpang sari mencapai 9,26 $\mathrm{cm} /$ tahun, sedangkan pohon karet monokultur hanya mencapai 8,54 $\mathrm{cm} /$ tahun. Sistem tumpang sari karet dengan tanaman sorgum dan kedelai dapat meningkatkan kesuburan lahan, sehingga laju pertumbuhan lilit batang pohon karet dengan pola tumpang sari lebih cepat daripada pohon karet monokultur (Tistama, Dalimunthe, Sembiring, Fauzi, Hastuti, \& Suharsono, 2016).

Pertumbuhan lilit batang pohon karet pola tumpang sari lebih tinggi, sehingga pohon karet lebih awal matang sadap daripada karet monokultur. Pola tumpang sari berpengaruh positif terhadap pertumbuhan karet selama lima tahun. Pohon karet dengan perlakuan tumpang sari siap untuk disadap lima bulan lebih awal daripada pada pohon karet monokultur. Hal ini mendukung hasil penelitian Esekhade, Idoko, Osazuwa, Kore, \& Mesike, (2014) yang menyatakan bahwa pohon karet yang ditanam secara tumpang sari dapat mencapai matang sadap lebih awal daripada yang ditanam secara monokultur. 
Romyen, Sausue, \& Charenjiratragul, (2018), juga menambahkan bahwa sistem tumpang sari karet dapat memperpendek waktu sadap, sehingga mempercepat pengembalian investasi.

Sementara ketebalan kulit pohon karet yang diperlakukan tumpang sari dengan pohon karet yang monokultur ternyata tidak berbeda signifikan. Begitu juga perlakuan tumpang sari tidak ada pengaruh yang konsisten terhadap hasil lateks per pohon per penyadapan. Namun, hasil per ha lateks dari lahan yang ada tumpang sari ternyata lateksnya lebih banyak daripada karet yang monokultur. Hal ini dikarenakan jumlah pohon yang dapat disadap pada lahan yang ditumpangsarikan nyata lebih banyak. Mousavi \& Eskandari, (2011), melaporkan bahwa hasil lateks meningkat dengan tumpang sari karena tingkat pertumbuhan lilit batang pohon karet lebih tinggi, sehingga jumlah pohon yang dapat disadap jumlahnya lebih banyak.

Sistem tumpang sari ini dapat meningkatkan produktivitas kebun karet, sehingga meningkatkan pendapatan petani. Sistem tumpang sari karet dapat meningkatkan produktivitas lahan kebun karet dan pendapatan rumah tangga petani (Romyen, Sausue, \& Charenjiratragul, 2018; Sahuri, 2019c). Sistem tumpang sari karet lebih menguntungkan secara ekonomi daripada yang monokultur (Snoeck, Lacotea, Kéli, Doumbiac, Chapuseta, Jagoretd, \& Goheta, 2013; Romyen, Sausue, \& Charenjiratragul, 2018).

\section{KESIMPULAN DAN SARAN}

\section{A. Kesimpulan}

Pola tumpang sari karet dengan tanaman jangka pendek memberikan penghasilan tambahan yang nyata selama periode pertumbuhan pohon karet belum matang sadap, ketika tidak ada lateks yang diproduksi. Pola tumpang sari berpengaruh nyata terhadap peningkatan pertumbuhan pohon karet dan mengurangi fase tanaman belum menghasilkan yang tidak produktif. Pola tumpang sari memiliki pengaruh positif terhadap pertumbuhan karet sampai umur lima tahun. Pohon karet dengan perlakuan tumpang sari siap untuk disadap lima bulan lebih awal daripada pada pohon karet monokultur. Sementara ketebalan kulit batang pohon karet tidak berbeda nyata dengan pohon karet monokultur. Perlakuan tumpang sari tidak ada pengaruh yang konsisten terhadap hasil lateks per pohon per penyadapan, tetapi hasil per ha lebih banyak dengan perlakuan tumpang sari karena jumlah pohon yang dapat disadap lebih banyak.

\section{B. Saran}

Diperlukan penelitian sistem tumpang sari berbasis karet yang lebih komprehensif pada berbagai lokasi tanaman karet. Pengembangan teknologi tumpang sari karet + tanaman ekonomi lainnya (nanas, jagung manis, dan cabai rawit) diperlukan dukungan dari berbagai pihak. Dalam operasionalisasi di lapangan, bimbingan teknis dan penguatan kelembagaan ekonomi seperti lembaga pengolahan, penyimpanan, dan pemasaran hasil memegang peranan penting.

\section{UCAPAN TERIMA KASIH}

Ucapan terimakasih kepada Ir. M. Jahidin Rosyid, M.S. sebagai peneliti utama yang telah memberikan masukan dan saran dalam penulisan makalah ini. Ucapan terima kasih juga disampaikan kepada Oktalisa Yuna, S.P. sebagai teknisi yang telah membantu terlaksananya penelitian ini.

\section{DAFTAR PUSTAKA}

As-syakur, A.R. (2009). Evaluasi zona agroklimat dari klasifikasi SchimidtFerguson menggunakan aplikasi Sistem Informasi Geografi (SIG). Jurnal Pijar MIPA, 3(1), 17-22. 
Esekhade, T.U., Idoko, S.O., Osazuwa, Kore, I.K., \& Mesike, C.S. (2014). Effect of intercropping on the gestation period of rubber. Journal of Agricultural Research, 3(8), 150-153.

Ferry, Y., Pranowo, D., \& Rusli. (2013). The effect of intercropping on the growth of immature rubber in a gradual felling system. Buletin Riset Tanaman Industri, 4, 225-230.

Fikriati, M. (2010). Adaptation test of soybean (Glycine max (L.) Merr.) shade tolerance under rubber in rubber smallholder in Sarolangun District, Jambi. [Skripsi]. Institut Pertanian Bogor.

Hondrade, R.F., Edwin, H., Zheng, L., Elazegui, F., Lynne, J.A., Duque, E., Christopher, C.M., Casiana M.VC., \& Garrett, K.A. (2017). Cropping system diversification for food production in Mindanao rubber plantations: a rice cultivar mixture and rice intercropped with mungbean. Peer Journal, 5, 1-20. DOI 10.7717/peerj.2975.

Khongdee, N., \& Pansak, W. (2015). Effect of rubber intercropping on plant nutrients and soil moisture on slop land of Northern Thailand. Research \& Innovation, 475-482. https://www.researchgate.net/publicati on/283623721.

Mousavi, S.R., \& Eskandari, H. (2011). A general overview on intercropping and its advantages in sustainable agriculture. J. Appl. Environ. Biol. Sci., 1(11), 482-486.

Ogwuche, P., Umar, H.Y., Esekhade, T.U., \& Francis, S.Y. (2012). Economies of intercropping natural rubber with arable crops: a panacea for poverty alleviation of rubber farmers. Journal of Agriculture Social Science, 8, 100102.

Pansak, W. (2015). Assessing rubber intercropping strategies in Northern Thailand using the water, nutrient, light capture in agroforestry systems model. Kasetsart Journal, 49, 785-
794.

Pringadi, K., Toha, H.M., \& Guswara, A. (2012). NPK fertilization of upland rice as rubber intercrops in rubber immature. Jurnal Soil Rens, 2, 133141.

Romyen, A. Sausue, P., \& Charenjiratragul, S. (2018). Investigation of rubberbased intercropping system in Southern Thailand. Kasetsart Journal of Social Sciences, 39, 135-142. https://doi.org/10.1016/j.kjss.2017.12. 002 2452-3151.

Sahuri, \& Rosyid, M.J. (2015). Optimization of land between rubber rows using cayenne pepper (Capsicum frutescens Linn.) as intercrops. Warta Perkaretan, 34, 77-88.

Sahuri, Cahyo, A.N., \& Nugraha, I.S. (2016). Rubber-rice intercropping system at farmer level in tidal swamp (case study in Nusantara Village, Air Sugihan, OKI District, South Sumatra Province). Warta Perkaretan, 35, 107120.

Sahuri, \& Rosyid, M.J. (2018). Saptabina usahatani karet rakyat: pola usahatani karet. Palembang, Indonesia: Balai Penelitian Sembawa.

Sahuri. (2019). Technology of rubber-crop intercropping: constraints and opportunities of sustainable development. Jurnal Litbang Pertanian, 38(1), 23-34.

Sahuri, Cahyo, A.N., Ardika, R., Nugraha, I.S., Alamsyah, A., \& Nurmansyah. (2019c). Modification of rubber (Hevea brasiliensis Muell. Arg.) spacing for long-term intercropping. Journal of Tropical Crop Science, 6(1), 50-59.

Snoeck, D., Lacotea, R., Kéli, J., Doumbiac, A., Chapuseta, T., Jagoretd, P., \& Goheta, É. (2013). Association of hevea with other tree crops can be more profitable than hevea monocrop during first 12 years. Industrial Crops and Products, 43, 578-586. 
Tetteh, E.N., Abunyewa, A.A., Tuffour, H.O., Berchie, J.N., Acheampong, P.P., Ampofo, K.T., Dawoe, E., Logah, V., Agbenyega, O., Ennin, S.A., Nunoo, I., Melenya. C., Danquah, E.O., Barnes, V.R., \& Partey, S.T. (2019). Rubber and plantain intercropping: Effects of different planting densities on soil characteristics. PLoSONE, 14(1), e0209260. https://doi.org/10.1371/ journal.pone.0209260.

Tistama, R., Dalimunthe, C.I., Sembiring, Y.R.V., Fauzi, I.R., Hastuti, R.D., \& Suharsono. (2016). Intercropping of shorgum and soybean for increasing of land productivity in rubber immature (Hevea brasiliensis Muell Arg). Indonesian Journal of Natural Rubber Research, 34, 61-76.

Wijaya, T. (2015). The utilization of climate data to support agronomic practices in rubber plantation. Proceedings Int. Rub. Conf., 1-3 Nov. 2015, Vietnam.

Wijaya, T. (2018). Kesesuaian tanah dan iklim untuk tanaman karet. Warta Perkaretan, 27(2), 34-44.

Xianhai, Z., Mingdao, C., \& Weifu, L. (2012). Improving planting pattern for intercropping in the whole production span of rubber tree. African Journal of Biotechnology, 11, 8484-8490. 